\title{
Mammographic Breast Densities among 200 Nigerian Females in Sokoto, North Western Nigeria
}

\author{
SULE Muhammad Baba ${ }^{1 *}$, Shamaki Amina Muhammad ${ }^{1}$, SA'IDU Sule Ahmed ${ }^{1}$, SADISU Mohammed Ma'aji ${ }^{1}$, YUNUSA Garba Haruna \\ 1, GELE Ibrahim Haruna ${ }^{2}$, SHIRAMA Yakubu Bababa ${ }^{2}$ \\ ${ }^{1}$ Department of Radiology, Usmanu Danfodiyo University, Sokoto, Nigeria. \\ ${ }^{2}$ Department of Radiology Gombe State University, Gombe, Nigeria.
}

*Corresponding Author: SULE Muhammad Baba, Department of Radiology, Usmanu Danfodiyo University Teaching Hospital, Sokoto. Nigeria.

Received date: June 07, 2021; Accepted date: August 07, 2021; Published date: August 25, 2021

Citation: SULE Muhammad Baba, Shamaki Amina Muhammad, SA'IDU Sule Ahmed, SADISU Mohammed Ma'aji, YUNUSA Garba Haruna, GELE Ibrahim Haruna, SHIRAMA Yakubu Bababa (2021) Mammographic Breast Densities among 200 Nigerian Females in sokoto, North Western Nigeria. J, Clinical Medical Reviews and Reports. 3(7); DOI:10.31579/2690-8794/090

Copyright: (C) 2021, SULE Muhammad Baba, This is an open access article distributed under the Creative Commons Attribution License, which permits unrestricted use, distribution, and reproduction in any medium, provided the original work is properly cited.

\begin{abstract}
Background: Breast density has been reported to be an independent predictor of breast cancer risk. Women with highest mammographic breast density may have four to six fold increased risk of developing cancer.

Aim and Objective: This study is aimed at evaluating the various forms of breast densities following screening and diagnostic mammographic examination.

Materials and Methods: From December 2010 and November 2012, 200 females had mammographic breast examination. Seventy-seven (77) females had routine screening mammography while 123 had diagnostic mammographic examination in the department with the General Electric (GE) Alpha-RT machine with model number MGF101(manufactured 2010).

All the subjects had to fill a mammographic form consisting of variables like age, sex, occupation, family history of breast cancer, tribe, contraception, parity, and caffeine consumption, history of surgical intervention (lumpectomy, biopsy and/or mastectomy), previous mammography and last child birth. MLO and CC views were done for the breast examination though additional views were occasionally employed.
\end{abstract}

Results: Breast density decreases with increase in age of the female subjects and breast lesions are better detected following mammography on fatty or less dense breast.

Keywords: breast density, mammography, sokoto, nigeria

\section{Introduction}

Mammography is a radiographic imaging technique for screening and diagnosis of breast pathologies using low energy ionizing radiation in the range of 20-35 KV. It has an advantage over ultrasonography and magnetic resonance imaging (MRI) techniques due to its reported high sensitivity and specificity, non-operator dependence, relative availability and affordability $[1,2,3]$.

Mammographic breast density (MBD) is dependent on the relative proportion of radiolucent fat and radio-dense connective and glandular tissue. This reflects the tissue composition of the breast [4].

Radiologically, dense tissue in the breast indicates stroma and epithelium, whereas lucent tissue indicates fat $[1,5]$. However changes in the breast tissue composition occur with increasing age, with the amount of stroma and epithelium decreasing and the amount of fat increasing $[1,6]$.
Mammographic breast density is important in that it affects mammographic screening sensitivity $[3,7]$.

Breast density has been reported to be an independent predictor of breast cancer risk. Women with highest mammographic breast density may have four to six fold increased risk of developing breast cancer compared to those with less breast density [1].

The first qualitative classification of mammographic breast density patterns was developed by Wolfe in 1976. He proposed a classification scheme for mammograms (xerograms) based on the appearance of the parenchyma [8] (See Table 1). Wolfe also suggested that mammographic appearance of the breast parenchyma might be useful in appraising a predisposition to carcinoma [9].

Apart from the renowned Wolfe classification, Tabaralso proposed a modification of Wolfe's classification [7]. 
More recently, other classification methods have become popular most likely due to changes in mammographic practices. The American College

\begin{tabular}{|l|l|}
\hline Categories & B \\
\hline N1 & b1 \\
\hline P2 & F \\
& oct \\
& B \\
\hline DY & S \\
& c \\
& B \\
& t \\
\hline
\end{tabular}

of Radiology (ACR) proposed a modified version of the Wolfe patterns for BIRADS classification [10] (See Table 2).

Breast density/cancer risk

Mostly fatty tissue with no ducts visible. Essentially normal breast and considered low risk.

Fatty breast with predominant duct in the anterior portion occupying up to a quarter of the breast area. Considered low risk

Breast involutes, with prominent duct patterns of moderate to severe degree occupying more than a quarter of the breast. The visible duct pattern may occupy the entire breast. High risk category.

Breast parenchyma is dense which usually denotes connective tissue hyperplasia. Considered as the highest risk pattern. May appear homogeneous due to the overall increased density.

Table 1: Wolfe classification

\begin{tabular}{|l|l|}
\hline BIRADS Category & Breast density. \\
\hline 1 & $\begin{array}{l}\text { Almost entirely fatty. Glandular tissue less than 25\% of the } \\
\text { breast. }\end{array}$ \\
\hline 2 & $\begin{array}{l}\text { Scattered fibroglandular densities. Glandular tissue } 25 \%-50 \% \\
\text { of the breast. }\end{array}$ \\
\hline 3 & $\begin{array}{l}\text { Heterogeneously dense. Glandular tissue } 51 \%-75 \% \text { of the } \\
\text { breast. }\end{array}$ \\
\hline 4 & Extremely dense. $>75 \%$ glandular tissue. \\
\hline
\end{tabular}

Table 2: showing the modified Wolfe classification

\section{Materials and Method}

Between December 2010 and November 2012, 77 females had routine screening mammography while 123 females had diagnostic mammography in the department with the General Electric (GE) AlphaRT machine with model number MGF-101 (manufactured 2010). All the subjects had to fill a mammographic form consisting of variables like age, sex, occupation, family history of breast cancer, tribe, contraception, parity, and caffeine consumption, history of surgical intervention (lumpectomy, biopsy and/or mastectomy), previous mammography and last child birth. MLO and CC views were done for the breast examination though additional views were occasionally employed. The images were acquired on the special single emulsion mammographic film. These and the obtained Biodata were stored in the departmental archive. For this study, the mammograms of all the subjects and their filled Biodata were retrieved from the departmental archive. The required variables were recorded and the retrieved mammograms reported and subsequently analyzed using statistical software (SPSS version 17; statistical package for social sciences version 17).

Mammograms from adult females that had screening mammographic examination were included for this study while mammograms from females less than 40 years of age were excluded.

Ethical approval for the study was obtained from the Research and Ethical committee of UsmanuDanfodiyo University Teaching Hospital Sokoto. Analysis began with descriptive statistics (Mean and SD) for quantitative data and was followed by inferential statistics (chi square test) to determine associations. The results were presented in form of tables. All statistical tests were carried out using chi square tests, with level of significance set at 0.05 .

\section{Results}

\section{Screening mammographyoutcome}

Demographics:

Mammograms from seventy-seven (77) adult females who had screening mammography were analyzed. The age range of the subjects was 40-59 years with a mean age of $45.7 \pm 5.4$. The patients were grouped into 5 years age strata. There were $40(51.9 \%)$ Hausa, $20(26 \%)$ Yoruba and 17 (22.1\%) Igbo subjects.

The prevalence of screening mammography within the stated period was $38.5 \%$. Seventy-seven females had screening mammography out of the 200 recruited subjects. The minimum age recruited was 40 years. All the subjects who had screening mammography had no complaints.

Breast densities were categorized similar to that done by the ACR in to four categories; the BIRADS 1 category(entirely fatty) was seen in 32 subjects (41.6\%), BIRADS 2 category (mixed fatty) in 32 subjects (41.6\%), BIRADS 3 category (mixed glandular) in 6 subjects $(7.8 \%)$ while BIRADS 4 category in $7(9.1 \%)$ subjects respectively. These are shown in Table 3.

In this study, it was found that age had a statistically significant association with breast density with a $p$ value of 0.03 . This is shown in Table 4.

The abnormal mammographic findings found in 26 (33.8\%) subjects who had screening mammography were masses, architectural distortion, isolated calcifications and nipple retraction in either or both breasts and were observed to have a statistically non-significant association with breast density $(\mathrm{p}=0.32)$.

\section{Diagnostic mammography outcome \\ Demographics:}

Mammograms from one hundred and twenty three (123) adult females who had diagnostic mammography were analyzed. The age range of the subjects was $30-59$ years with a mean age of $42.7 \pm 8.3$. The patients were grouped into 10 years age strata. There were 105 (85.4\%) Hausa, 10 $(8.1 \%)$ Yoruba and $8(6.5 \%)$ Igbo subjects.

The prevalence of diagnostic mammography within the stated period is $61.5 \%$. One hundred and twenty-three females had diagnostic mammography out of the recruited 200 subjects. The minimum age was 30 years. 
Amongst the 123 subjects who had diagnostic mammography, 50 (40.7\%) had pain in either or both breast as a presenting complaint, 46 (37.4\%) had lumps in either or both breasts, $16(13 \%)$ were confirmed cases of breast cancers in either breast, 7 (5.7\%) had bloody nipple discharge in either or both breast, $2(1.6 \%)$ had breast swelling in either breast while left nipple retraction and right axillary tender mass occurred in $0.8 \%$ (one case each).

Breast densities were categorized similar to that done by the ACR in to

four categories; the BIRADS 1 category(entirely fatty) was seen in 54 subjects $(43.9 \%)$, BIRADS 2 category (mixed fatty) in 20 subjects
(16.3\%), BIRADS 3 category (mixed glandular) in 14 subjects $(11.4 \%)$ while BIRADS 4 category in $35(28.5 \%)$ subjects respectively.

In this study, it was found that age had a statistically significant association with breast density with a $\mathrm{p}$ value of 0.00 . This is shown in Table 5.

The abnormal mammographic findings found in $61(49.6 \%)$ subjects following diagnostic mammography were masses, architectural distortion, isolated calcifications and nipple retraction in either or both breasts and were observed to have a statistically non-significant association with breast density $(\mathrm{p}=0.33)$.

\begin{tabular}{|l|l|l|}
\hline Variable & BIRADS CATEGORY & Frequency N (\%) \\
\hline Breast Density & & \\
\hline Fatty & 1 & $32(41.6)$ \\
\hline Mixed Fatty & 2 & $32(41.6)$ \\
\hline Mixed Glandular & 3 & $6(7.8)$ \\
\hline Glandular & 4 & $7(9.1)$ \\
\hline Total & & $77(100)$ \\
\hline
\end{tabular}

(The fatty and mixed fatty breast density categories were the most frequent following screening mammography).

Table 3: shows the various breast density categories of the subjects that had screening mammography.

\begin{tabular}{|l|l|l|l|l|l|}
\hline & & $\begin{array}{l}\text { Breast Density } \\
\text { (Frequency \%) }\end{array}$ & & Test Statistics \\
\hline Variable & & & & & \\
\hline $\begin{array}{l}\text { Age Group } \\
\text { years) }\end{array}$ & Glandular & Mixed Glandular & Mixed Fatty & Fatty & $\mathrm{X}^{2}=19.05 \mathrm{a}$ \\
\hline $40-44$ & $5(71.4)$ & $4(66.7)$ & $17(53.1)$ & $7(21.9)$ & $\mathrm{df}=9$ \\
\hline $45-49$ & $2(28.6)$ & $2(33.3)$ & $12(37.5)$ & $11(34.4)$ & pvalue=0.03 \\
\hline $50-54$ & $0(0)$ & $0(0)$ & $1(3.1)$ & $9(28.1)$ & \\
\hline $55-59$ & $0(0)$ & $0(0)$ & $2(6.3)$ & $5(15.6)$ & \\
\hline Total & $7(100)$ & $6(100)$ & $32(100)$ & $32(100)$ & \\
\hline
\end{tabular}

(A statistically significant relationship was noted between breast density and age with a $\mathrm{p}$ value of 0.03 ).

Table 4: shows association between mammographic breast density and age of the subjects that had screening mammography.

\begin{tabular}{|l|l|l|l|l|l|}
\hline & & $\begin{array}{l}\text { Breast Density } \\
(\text { Frequency \%) }\end{array}$ & Test Statistics \\
\hline Variable & & & & & \\
\hline $\begin{array}{l}\text { Age Group } \\
\text { (years) }\end{array}$ & Glandular & Mixed Glandular & Mixed Fatty & Fatty & $X^{2}=126.537 \mathrm{a}$ \\
\hline $30-39$ & $32(91.4)$ & $2(14.3)$ & $1(5.0)$ & $1(1.9)$ & $\mathrm{df}=6$ \\
\hline $40-49$ & $2(5.7)$ & $12(85.7)$ & $19(95.0)$ & $24(44.4)$ & pvalue=0.00 \\
\hline $50-59$ & $1(2.9)$ & $0(0)$ & $0(0)$ & $29(53.7)$ & \\
\hline Total & $35(100)$ & $14(100)$ & $20(100)$ & $54(100)$ & \\
\hline
\end{tabular}

(A statistically significant relationship was noted between breast density and age with a $\mathrm{p}$ value of 0.00 ).

Table 5: Association between Breast density and age of the recruited subjects.

\section{Discussion}

In this study the highest frequency of screening mammographic examination was found in the 40-44years age group. This conformed to the study of Kiguliet al [11] in Uganda and Ohlinger et al [12] in Germany.

In this study most of the study populations were married women which conformed to the studies of Okejiet al [13] in South eastern Nigeria and Obajimi et al [14] in south western Nigeria where most of the study population were married women. This finding differed considerably from the study of Kiguliet al [11] in Uganda who had only $10 \%$ of their study population to be married women and Adejumo et al [15] in Ibadan where most of the subjects were single. This variance is probably due to differences in cultural practices.

Most of the subjects in the study population were Hausa's and invariance to the study of Obajimiet al [14] in Ibadan where the Yoruba tribe predominated. This is because the study area is predominantly inhabited by them.

Breast density was categorized according to ACR classification as glandular, mixed glandular, mixed fatty and fatty. In this study, the fatty parenchymal pattern was predominant in $41.6 \%$ among those who had screening mammography. This is at variance to the predominant mixed fatty parenchyma reported by Akinolaet al in their study. This variance may be due to the fact that the predominant age population in this study was the 40-44 years age group in which involution of the breast glandular tissues has commenced.

The prevalence rate of screening mammography was found to be $38.5 \%$ in Sokoto within the study period; this is similar to that reported by Rachael et al [17] in Lagos Nigeria. This is lower when compared to that reported by Awosanya [2] and Akinolaet al [16] both in Lagos, Nigeria. This is probably due to availability of the facility before Sokoto and 
increased awareness of the benefits of breast screening in Lagos. The prevalence of diagnostic mammography was found to be $61.5 \%$. This agrees with the study of Awosanya [2]. The most frequent presenting complaint for those who had diagnostic mammography were breast lumps and pain in either or both breasts which were in conformity to the aforementioned studies [2, 16]. This is probably due to the same geographical location, race and almost similar cultural practices.

In this study it was found that most of the subjects came for diagnostic mammography rather than screening. Seventy-seven subjects had screening while 123 subjects had diagnostic mammography. Similar findings were also observed by Awosanya [2] and Akinolaet al [16] in Lagos, Nigeria. This is most likely from anxiety, lack of awareness of the benefits of mammographic screening and cost implication.

Breast density was categorized according to ACR classification as glandular, mixed glandular, mixed fatty and fatty. In this study, the fatty parenchymal pattern was predominant in $43.9 \%$ among those who had diagnostic mammography. This is at variance to the predominant mixed fatty parenchyma reported by Akinolaet al [16] in their study. This variance may be due to the fact that the predominant age population in this study was the 40-49 years age group in which involution of the breast glandular tissues has commenced.

\section{Conclusion}

In this study it was found out that breast density decreases with increase in age of the female subjects and breast lesions in form of abnormal findings which include masses, architectural distortion and isolated calcification were better demonstrated following mammography on fatty or less dense breast.

\section{References}

1. S Bassey, T O Soyemi, A T Adeniji-Sofoluwe, A O Adeye, O Mosuru, T S Akingbola et al. (2016) Mammographic Breast Pattern in Postmenopausal Women in Ibadan, South-Western Nigeria. B.JMMR.17:1-10.

2. Awosanya GO, Jeje EA, Bayagbona D, Inem VA. (2004) Screening and diagnostic Mammographic findings of 115 consecutive Nigerian women: A two year study in a City Private Hospital. NigQt J Hosp. Med. 14: 166 - 168.

3. Sylvia H H-K, Dershaw DD, Ingro S. (2001) Diagnostic Breast Imaging. 2nded. New York: Theme Stuggart. 3: 14 - 60.

4. MO Obajimi, ATS Adeniji-Sofoluwe, A Oluwasola, BO Adedokun, TO Soyemi, F Olopade et al. (2011) Mammographic breast pattern in Nigerian women in Ibadan, Nigeria. Breast Disease. 33:9-15.

This work is licensed under Creative Commons Attribution 4.0 License

To Submit Your Article Click Here: Submit Manuscript

DOI: $10.31579 / 2690-8794 / 090$
5. Ingleby H, Gerson-Cohen J. (1960) Comperative anatomy, pathology and roentgenology of breast. University of Philadelphia Press, Philadelphia. 230-238.

6. Grove JS, Goodman MJ, Gilbert FL Jr, Mi MP. (1985) Factors associated with mammographic pattern. Br J Radiol. 58:21-25.

7. G Marcela, FH Elkan, BK Daniels, M Beverly, HM Richards, EG Paul et al. (2007) Mammographic Breast Density and Race. AJR. 188:1147-1150.

8. Styliani P, Timor K, Micheal B. (2017) Automatic classification of mammographic parenchymal patterns: A statistical approach.

9. Wolfe JN. (1969) The prominent pattern as an indicator of cancer risk. Oncology. 23:149-158.

10. American College of Radiology (ACR), ACR BI-RADS mammography 4th edition. In ACR Breast Imaging Reporting and Data System, Breast Imaging Atlas. Reston, V.A: American College of Radiology, 2003.

11. Kiguli NE, Mubuuke AG, Businge F, Kawooya GM, Nakatudde R, Byanyima KR, et al. (2010) Current knowledge, attitudes and practices of women on breast cancer and mammography at Mulago hospital. Pan Afr Med J. 5:9-21.

12. Ohlinger R, Heyer H, Thomas A, Paepke S, Warm H, Klug U, et al. (2006) Non palpable breast lesions in initial ultrasonography and comparison with mammography. Anticancer Res. 26: 3943 $-3956$.

13. Mark CO, Benjamin EU, Ndubuisi OC. (2012) Anxiety in women presenting for mammography in Nigeria: causes and implication. Br J Sc. 4: $44-48$.

14. Obajimi MO, Ajayi OI, Oluwasola OA, Adedokun OB, AdenijiSofoluwe TA, Mosure AO et al. (2013) Level of awareness of mammography among women attending outpatient clinics in a teaching hospital in Ibadan, South-Western Nigeria. BMC Public Health. 13: 40-47.

15. Adejumo PO, Aluko JO, Oluwatosin OA. (2008) Awareness of Breast Cancer among Female Undergraduate Students of University Of Ibadan, Nigeria. Afr J for the PsycholSoc Issues. 11: 161-173.

16. Akinola RA, Akinola OI, Shittu LA, Balogun BO, Tayo AO. (2007) Appraisal of mammography in Nigerian women in a New Teaching Hospital. Acad J. 8: 325 - 329.

17. Racheal A, Kikelomo W, Oludamilola O, Olubunmi O, Oluwarotimi A. (2011) Mammography and Mammographic screening: are female patients at a Teaching Hospital in Lagos, Nigeria aware of these procedures? DignIntervRadiol. 17: 125 129.
Ready to submit your research? Choose Auctores and benefit from:

* fast, convenient online submission

* rigorous peer review by experienced research in your field

* rapid publication on acceptance

* authors retain copyrights

* unique DOI for all articles

* immediate, unrestricted online access

At Auctores, research is always in progress.

Learn more www.auctoresonline.org/journals/clinical-medical-reviewsand-reports 